\title{
An Efficient and Chemoselective Method for Synthesis of 1,3-Oxathiolanes from Aldehydes and their Deprotection Catalyzed by $\mathrm{V}\left(\mathrm{HSO}_{4}\right)_{3}$
}

\author{
F. Shirini,; M. Aledini, M. Ghasemi, and A. R. Sakhaei \\ Department of Chemistry, College of Science. The Lniversity of Guilan. Rasht-Iran. E-mail: shiminiāguilanac.ir \\ Recerved Hay 28, 2009, Accepted September 3, 2009
}

Key Words: $\mathrm{V}\left(\mathrm{HSO}_{4}\right)_{3}, 2-\mathrm{Mercaptoethanol,} \mathrm{1,3-Oxathiolane,} \mathrm{Oxathioacetalyzation.} \mathrm{Aldehỵdes}$

The carbonyl group plays a predominant role in organic synthesis due to its electrophilic nature. One of the major common problems during many multi-step syntheses in organic. medicinal, carbohydrate and drug design chemistry is how to protect the carbonyl group from nucleophilic attack until its electrophilic properties could be utilized. Therefore the protection and deprotcetion of carbonyl groups remain an area of interest in synthetic organic chemistry. Among the carbonyl protecting groups. 1,3-oxathiolanes are important class of compounds that are more stable than corresponding $\mathrm{O} . \mathrm{O}$-acetals under acidic conditions and compared with S.S-acetals are more easily deprotected. ${ }^{1}$ In addition, 1.3-0.xathiolanes can be utilized as acylation equivalents in $\mathrm{C}-\mathrm{C}$ bond formation. Moreover, the chiral 1,3-oxathiolanes are valuable synthons for enantioselective sy'nthesis of $\alpha$-hyydroxyaldehy'dees. ${ }^{3} \mathrm{Di}$ fferent types of reagents have been used for the promotion of oxathioacetalization of carbonyl compounds with 2-maercaptoethanol which of them $\mathrm{HCl}^{+} \mathrm{HClO}_{4}{ }^{*} p-\mathrm{TsOH}^{6}{ }^{6} \mathrm{TMSOTf}^{\text {* }}$ $\mathrm{BF}_{3} \cdot \mathrm{OEt}_{-}{ }^{8} \mathrm{I}_{2}{ }^{9} \mathrm{TaCl}_{5} / \mathrm{SiO}_{3},{ }^{10} \mathrm{ZrCl}_{4},{ }^{11} \mathrm{PPA} / \mathrm{SiO}_{2}{ }^{12} \mathrm{NBS}^{13}$ $\mathrm{LiBF}_{+}{ }^{14} \mathrm{MoO}_{2}(\mathrm{acac})_{2},{ }^{15} \mathrm{Y}(\mathrm{OTf})_{3}{ }^{16}$ Amberlyst ${ }^{16}-15^{13} \mathrm{Fe}\left(\mathrm{CF}_{3}\right.$ $\left.\mathrm{CO}_{2}\right)_{3}$ and $\mathrm{Fe}\left(\mathrm{CF}_{3} \mathrm{SO}_{2}\right)_{3 .}{ }^{18}$ novel cataly st $\left\{\mathrm{H}-\left(\mathrm{C}_{10} \mathrm{H}_{3} \mathrm{SO}_{3} \mathrm{H}\right)-\right.$ $\left.\mathrm{CH}_{2}\right]_{12}-\mathrm{C}_{1}\left(\mathrm{H}_{6} \mathrm{SO}_{3} \mathrm{H}_{3}{ }^{19} \mathrm{H}_{3} \mathrm{PW}_{12} \mathrm{O}_{41} / \mathrm{SiO}_{2}{ }^{20} \mathrm{Sn}\left(\mathrm{HPO}_{4}\right)_{2} \cdot \mathrm{H}_{2} \mathrm{O}^{-1}\right.$ $\mathrm{Pr}(\mathrm{OTf})_{3}{ }^{2-} \mathrm{Me}_{2} \mathrm{~S}_{\mathrm{S}} \mathrm{Br}_{2}{ }^{23}$ and $[\mathrm{bmim}] \mathrm{BF}_{4}{ }^{2+}$ are examples. Although some of these methods afford good to high yields of the corresponding 1.3-oxathiolanes. the majority suffer from one or more of the following disadvantages: low yields, long reaction times. harsh reaction conditions. use of expensive. not readily available or moisture sensitive reagents, tedious work-up. poor chemoselectivity and the use of stoichiometric amounts of the catalyst. Therefore. introduction of new methods and catalysts for the preparation of 1.3 -oxathiolnes is still in demand

Recently we have reported the preparation of vanadium hydrogen sulfate and its application in the chemoselective trimethylsilylation and acetylation of alcohols. ${ }^{\geq 5}, 26$ In continutation of these studies. herein. we report the applicability of this reagent in the promotion of the oxathioacetalyzation of aldehydes with 2-mercaptoethanol. All reactions were performed in $n$-hexane at reflux temperature under completely heterogeneous reaction conditions in relatively short reaction

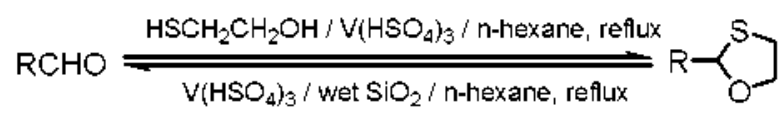

Scheme 1 times in excellent yields (Table 1, Scheme 1).

As shown in Table 1, different types of aromatic aldelydes. including different substituents such as $\mathrm{Cl} . \mathrm{Br}, \mathrm{Me}$ and $\mathrm{NO}_{2}$ are converted to their corresponding 1,3-oxathiolanes in good to high yields (Table 1 , entries 1-9). This method is also very useful for the oxathioacetalyzation of aliphatic aldehydes (Table 1 , entries 10-12). Acid and heat sensitive furfural afforded the desired product under the same reaction conditions (Table 1. entry 13). Ketones are so stable under the same reaction conditions. that the starting material was recovered unchanged after 30 min (Table 1 , entries 14.15 ). This indicates that the present method is applicable for the chemoselective protection of aldelydes in the presence of ketones. This is examplified by the competitive of t-chlorobenzaldehyde in the presence of phenylacetone (Table 1 . entry 16).

In order to show the efficiency of this method, Table 2 compares the results obtained from the oxathioacetalization of

Talble 1. Oxathioacetalyzation of aldehydes and deprotection of 1,3-oxathiolanes. ${ }^{a . t}$

\begin{tabular}{|c|c|c|c|c|c|}
\hline \multirow[b]{2}{*}{ Entry } & \multirow[b]{2}{*}{ Substrate } & \multicolumn{2}{|c|}{ Protection } & \multicolumn{2}{|c|}{ Deprotection } \\
\hline & & $\begin{array}{l}\text { Tmie } \\
\text { (min) }\end{array}$ & $\begin{array}{l}\text { Yield } \\
(\%)\end{array}$ & $\begin{array}{l}\text { Time } \\
\text { (min) }\end{array}$ & $\begin{array}{c}\text { Yield } \\
(\%)\end{array}$ \\
\hline 1 & $\mathrm{PhCHO}$ & 15 & 95 & 60 & 90 \\
\hline 2 & $2-\mathrm{MeC}_{6} \mathrm{H}_{4} \mathrm{CHO}$ & 15 & 87 & 90 & 85 \\
\hline 3 & $4-\mathrm{MeC}_{4} \mathrm{H}_{+} \mathrm{CHO}$ & 15 & 90 & 75 & 87 \\
\hline 4 & $2-\mathrm{ClC}_{6} \mathrm{H}_{4} \mathrm{CHO}$ & 10 & 92 & 30 & 90 \\
\hline 5 & $3-\mathrm{ClC}_{4} \mathrm{H}_{4} \mathrm{CHO}$ & 10 & 90 & 30 & 92 \\
\hline 6 & $4-\mathrm{ClC}_{6} \mathrm{H}_{4} \mathrm{CHO}$ & 7 & 95 & 25 & 95 \\
\hline 7 & $2-\mathrm{BrC}_{6} \mathrm{H}_{4} \mathrm{CHO}$ & 15 & 92 & 15 & 92 \\
\hline 8 & $2-\mathrm{NO}_{2} \mathrm{C}_{6} \mathrm{H}_{4} \mathrm{CHO}$ & 7 & 90 & 70 & 50 \\
\hline 9 & $3-\mathrm{NO}_{2} \mathrm{C}_{6} \mathrm{H}_{4} \mathrm{CHO}$ & 15 & 95 & 60 & 90 \\
\hline 10 & $\mathrm{PhCH}_{2} \mathrm{CH}_{2} \mathrm{CHO}$ & 10 & 92 & 90 & 92 \\
\hline 11 & $\mathrm{PhCH}(\mathrm{Me}) \mathrm{CHO}$ & 12 & 95 & 65 & 90 \\
\hline 12 & $\mathrm{MeCH}_{2} \mathrm{CH}_{2} \mathrm{CH}_{2} \mathrm{CHO}$ & 10 & 92 & 45 & 85 \\
\hline 13 & 0 & 20 & 90 & 40 & 90 \\
\hline 14 & $\mathrm{PhCH}_{2} \mathrm{COCH}_{3}$ & 30 & 0 & - & - \\
\hline 15 & $\mathrm{PhCOCH}_{3}$ & 60 & 0 & - & - \\
\hline 16 & $\begin{array}{c}\mathrm{PHCH}_{2} \mathrm{COCH}_{3} \\
+ \\
4-\mathrm{ClC}_{6} \mathrm{H}_{4} \mathrm{CHO}\end{array}$ & 15 & $\begin{array}{c}0^{\mathrm{c}} \\
+ \\
100^{\mathrm{k}}\end{array}$ & - & - \\
\hline
\end{tabular}

${ }^{a}$ Products were characterized by comparison with authentic samples and IR and NMR spectroscopy. "Isolated yields. "Conversion. 
Table 2. Comparison of the efficiency of $\mathrm{V}\left(\mathrm{HSO}_{4}\right)$ : with other reported catalysts in the oxathioacetalyzation of benzaldehyde.

\begin{tabular}{|c|c|c|c|c|c|}
\hline Entry & Reagent & $\begin{array}{c}\text { Catalyst } \\
\text { load }\end{array}$ & $\begin{array}{l}\text { Time } \\
\text { (minin) }\end{array}$ & $\begin{array}{l}\text { Yield } \\
(\%)\end{array}$ & Ref. \\
\hline 1 & $\mathrm{PPA} / \mathrm{SiO}_{2}$ & $0.5 \mathrm{~g}$ & 30 & 99 & 12 \\
\hline 2 & $\mathrm{MoO}_{2}(\mathrm{acac})_{2}$ & $22 \mathrm{mgg}$ & 240 & 86 & 15 \\
\hline \multirow[t]{2}{*}{3} & Amberlyst ${ }^{15}-15$ & $220 \mathrm{mg}$ & 60 & 84 & 17 \\
\hline & & $60 \mathrm{mg}$ & 25 & 96 & 19 \\
\hline 5 & $\mathrm{Sn}\left(\mathrm{HPO}_{4}\right)_{2} \cdot \mathrm{H}_{2} \mathrm{O}$ & $5 \mathrm{~m} n \mathrm{ol} \%$ & 30 & 96 & 21 \\
\hline 6 & [bmim] $\mathrm{BF}_{4}$ & $2 \mathrm{~mL}$ & 150 & 92 & 24 \\
\hline 7 & $\mathrm{~V}\left(\mathrm{HSO}_{4}\right)_{3}$ & $3 \mathrm{~m} n \mathrm{ol} \%$ & 15 & 95 & $\begin{array}{l}\text { Present } \\
\text { method }\end{array}$ \\
\hline
\end{tabular}

benzaldehyde by our method with some of those reported in the literature.

Our investigations clarified that the deprotection of 1.3oxathiolanes can also be easily catalyzed in the presence of a mixture of $\mathrm{V}\left(\mathrm{HSO}_{4}\right)_{3}$ and wet $\mathrm{SiO}_{2}$ (Table 1. Scheme 1). The reaction is efficient and the corresponding aldehy'des are separated in high yields.

In conclusion. in this study, we have developed a mild. efficient and chemoselective method for oxathioacetalization of aldehydes. in the presence of ketones. and their deprotection. The significant advantages of this methodology are mild and heterogeneous reaction conditions, relatively short reaction times. high yields of the products. selectivity and easy work-up. We are exploring further applications of $\mathrm{V}\left(\mathrm{HSO}_{4}\right)_{3}$ for the other types of functional group transformations in our laboratory

\section{Experimental}

Oxathioacetalyzation of 4-chlorobenzaldehyde as a typical procedure. A mixture of t-chlorobenzaldehyde (1 munol). 2mercaptoethanol $(1.2 \mathrm{mmol})$ and $\mathrm{V}\left(\mathrm{HSO}_{4}\right)_{3}(0.03 \mathrm{mmol})$ in $n$-hexane ( $3 \mathrm{~mL}$ ) was stirred at reflux temperature. The progress of the reaction was monitored by TLC. After completion of the reaction. the mixture was filtered and the filtrate was washed with $n$-hexane $(5 \mathrm{~mL})$. The organic layer was washed with a saturated solution of $\mathrm{NaHCO}_{3}(2 \times 5 \mathrm{~mL})$ and water $(10$ $\mathrm{mL}$ ) and dried over $\mathrm{MgSO}_{4}$. Eevaporation of the solvent followed by column chromatography on silica gel gave $2-\left[4^{\circ}-\right.$ chlorophenyl]-1.3-oxathiolane in $95 \%$ yield. IR (neat) $1598,1496$. 1414. 1209. 1091. $1015 \mathrm{~cm}^{-1}$; $1 \mathrm{H} \mathrm{NMR}\left(300 \mathrm{MHz}, \mathrm{CDCl}_{3}\right)$ oे $3.10-3.23(\mathrm{~m} .2 \mathrm{H}) .3 .82-3.92(\mathrm{~m} .1 \mathrm{H}) .4 .41-4.54(\mathrm{~m} . \mathrm{lH}) .5 .94$ $(\mathrm{s}, 1 \mathrm{H}) .7 .30$ (d. $2 \mathrm{H}), 7.44$ (d. $2 \mathrm{H}$ ). Anal. Calcd for $\mathrm{C}_{9} \mathrm{H}_{9} \mathrm{ClOS}: \mathrm{C}$,
53.86: H. 4.52 : S, $15.98 \%$. Found C. $53.63 ;$ H. $4.59 ;$ S, $15.77 \%$.

Deprotection of 2-[4'-chloropheny]]-1,3-0xathiolane as a typical procedure. A mixture of the substrate ( $1 \mathrm{mmol}$ ). $\mathrm{V}\left(\mathrm{HSO}_{4}\right)_{5}(0.5 \mathrm{mmol})$ and wet $\mathrm{SiO}_{2}\left[\left(\mathrm{SiO}_{2} / \mathrm{H}_{2} \mathrm{O}: 50 \%\right.\right.$ w $0.1 \mathrm{~g}]$ in $n$-hexane ( $3 \mathrm{~mL}$ ) was stirred and heated at reflux. The progress of the reaction was monitored by TLC. After completion of the reaction. the mixture was filtered and the solid residue was washed with $n$-hexane $(5 \mathrm{~mL})$. The organic layer was washed with saturated $\mathrm{NaHCO}_{3}(2 \times 5 \mathrm{~mL})$ and water (10 $\mathrm{mL}$ ) and dried over $\mathrm{MgSO}_{4}$. Evaporation of the solvent followed by colunu chromatography on silica gel afforded 4-chlorobenzaldehyde in $95 \%$ yield.

Acknowledgments. We are thankful to the University of Guilan Research Council for the partial support of this work.

\section{Refeiences}

1. Smith, A. B.; Condon, S. M.; McCauley, T. A. Acc. Chent Res. $1998,31,35$

2. Eliel, E. L.; Morris-Natschle, S. J. Am. Chem. Soc. 1984, 106, 2937.

3. Lynch, J. E.; Eliel, E. L. J. Am. Chem. Soc. 1984, 106, 2943.

4. Ralls, J. W.: Dodson, R. M.; Riegel, B. J. Am. Chem. Soc. 1949, 71,3320 .

5. Djerassi, C. Gorman, M. J.Am. Chem. Soc. 1953, 75.3704.

6. Mondal, E.; Sahu, P. R.; Khan, A. T. Smlett 2002, 463.

7. Ravindranathan, T.; Chavan, S. P.; Dantale, S. W. Tetrahedron Lett. $1995,36,2285$

8. Wilson, Ir., G. E.: Huleng, M. G.: Schloman, Jr., W. W. J. Org. Chem. 1968, 33,2133.

9. Bandgar, B. P.; Bettigeri, S. V. J. Chent. Res.(S) 2004, 389

10. Chandrasekhar, S.; Prakash, S. T.; Shyamsunder, T; Ramachandar, T. Sinth. Commun. 2005, 35, 3127 .

11. Karimi, B.; Seradj, H. Sinlett 2000, 805

12. Aovama. T: Takido. T.: Kodomari. M. Smlet 2004. 2307

13. Kamal, A.; Choulhan, G.; Ahmed, K. Tetrahedron Lett. 2002, 43, 6947 .

14. Yadav, J. S.; Reddy, B. V. S.: Pandey, S. K. Sinlett 2001, 238.

15. Rana, K. K.: Guni. C.: Jana, S.: Roy, S. C. Tetrahedron Lett. $2003,4,8597$

16. Kanta De. S. Tetwhedron Lett. 2004, 45, 2339.

17. Ballini, R.: Bosica, G.; Maggi, R.; Mazzacani, A.; Righi, P.; Sartori. G. Stmthesis 2001, 1826

18. Adibi, H.: Jâtari, H. J. Fhome Chem 2007, 128,679

19. Liang, $\mathrm{X}$.; Gao, S.; Yang, T; He, M. Catal. Commun. 2008, 10 , 156

20. Firolzabadi, H.: Iranpoor, N.: Jafäri, A. A.; Tafari, M. R. J.Mol. Catal A. Chem. 2006, 2+7, 14

21. Hazarika, P.; Sharma, S. D.; Konwar, D. Catal. Commun. 2008, 9,2398

22. Suryá, D. K. Sinthesis 2004. 2837

23. Yadav, I. S.; Reddy, B. V. S.; Kondaij, G. Chem. Lett. 2003, 32 , 672

25. Shirini, F.; Zolfigol, M. A:; Abedini, M.; Sakhaei, A. R. $J$. Chinese Chem. Soc. 2008. 55.943

26. Shirini, F.; Sakhaei, A. R; Abedini, M. Chinese Chem. Lett. $2009,20,439$ 